J. Clin. Chem. Clin. Biochem.

Vol. 21, 1983, pp. 31-33

\title{
Influence of Bilirubin on the Determination of Acid Phosphatase in Serum
}

\author{
By G. E. Hoffmann and L. Weiss \\ Institute of Clinical Chemistry, Harlaching City Hospital, München
}

(Received May 27/August 5, 1982)

\begin{abstract}
Summary: Bilirubin interferes greatly in the continuous measurement of acid phosphatase, using $\alpha$-naphthyl phosphate as substrate and diazotized 2-amino-5-chlorotoluene (Fast Red TR) as the colorimetric reagent. Fast Red TR and the so-called "direct" (but not "indirect") bilirubin form a coloured azo-compound which absorbs light above $480 \mathrm{~nm}$. Negative absorbance changes are observed at $405 \mathrm{~nm}$, which is used in the determination of acid phosphatase. This leads to apparently negative activities.
\end{abstract}

\section{Störung der Bestimmung der sauren Phosphatase im Serum durch Bilirubin}

Zusammenfassung: Die kontinuierliche Messung der sauren Phosphatase mit $\alpha$-Naphthylphosphat als Substrat und diazotiertem 2-Amino-5-chlortoluol (Fast Red TR) als Farbreagenz wird durch Bilirubin erheblich gestört. Sogenanntes "direktes" nicht jedoch "indirektes" Bilirubin bildet mit Fast Red TR ein farbiges Azoprodukt, das bei Wellenlängen jenseits von $480 \mathrm{~nm}$ absorbiert. Bei der Meßwellenlänge für die Reaktion der sauren Phosphatase ( $405 \mathrm{~nm}$ ) kommt es zu einem Absorptionsabfall, so daß negative katalytische Aktivitäten vorgetäuscht werden.

\section{Introduction}

In 1971, Hillmann (1) described a continuous method for the determination of acid phosphatase in serum, which is now widely used in clinical laboratories $(2,3)$. The procedure involves hydrolysis of $\alpha$-naphthyl-phosphate by acid phosphatase and subsequent formation of a coloured azo-compound (4) from the resulting $\bar{\alpha}$-naphthol and diazotized 2 -amino-5-chlorotoluene (Fast Red TR). It was pointed out by Hillmann (1) that bilirubin was not attacked by Fast Red TR under the conditions of the test. We, however, obșerved low or even "negative" values for acid phosphatase in icteric sera, suggesting a still unexplained interference of bilirubin or some bilirubin metabolite.

\section{Materials and Methods}

The following commercial reagents and test combinations were used:

bilirubin standard solution from DuPont, Wilmington, USA, dimethylformamide from Mirck, Darmstadt, Germany,
Fast Red TR from Serva, Heidelberg, Germany,

acid phosphatase test according to Hillmann (1) from Boehringer, Mannheim, Germany and from Smith and Kline Instruments, Palo Alto, USA,

bilirubin test according to Wahlefeld et al. (5) from Boehringer, Mannheim,

test for direct bilirubin according to Jendrassik \& Grof (6) from Gödeckè, Freiburg, Germany.

Measurements were performed on the photometer $1101 \mathrm{M}$ from Eppendorf Gerätebau, Hamburg, Germany. Absorption spectra were recorded on the Hitachi 156 double-wavelength spectrophotometer.

\section{Results}

Figure 1 shows a typical acid phosphatase reaction curve (A) recorded at $405 \mathrm{~nm}$ wavelength and $37^{\circ} \mathrm{C}$ with a non-icteric serum (bilirubin content $12 \mu \mathrm{mol} / \mathrm{l}$, catalytic concentration of acid phosphatase $61 \mathrm{U} / \mathrm{l}$ ). The sample volume is $0.05 \mathrm{ml}$ and the total cuvette volume $0.6 \mathrm{ml}$ in this experiment. When 10 to $50 \mu \mathrm{l}$ of the reagent mixture are replaced by a highly icteric serum without measurable phosphatase 
activity (bilirubin content $856 \mu \mathrm{mol} / \mathrm{l}$, direct bilirubin $616 \mu \mathrm{mol} / \mathrm{l})$, the resulting activity ( $5^{\text {th }}$ minute) is greatly decreased. Negative absorbance changes are observed during the first 4 minutes.

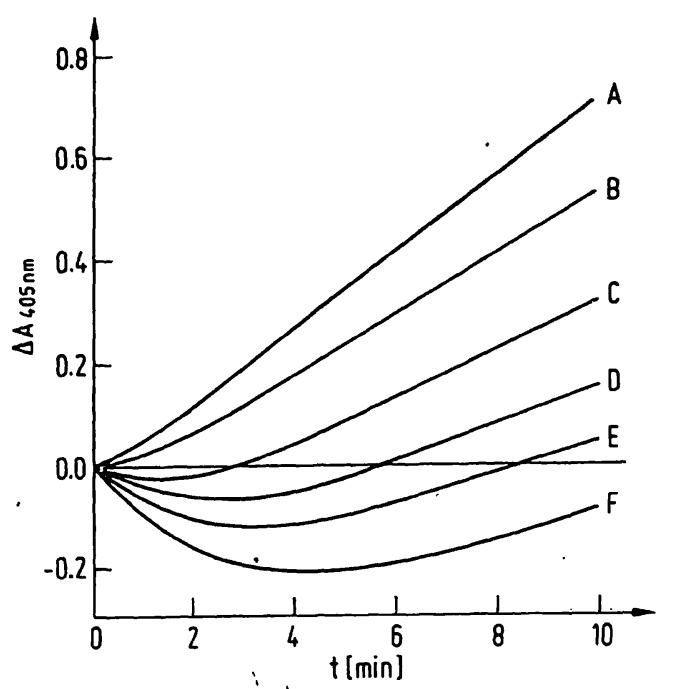

Fig. 1. Acid phosphatase determination $\left(37^{\circ} \mathrm{C}\right)$ in the presence of varying amounts of icteric serum. $\mathrm{A}=$ without icteric serum, $B-F=10,20,30,40$, and $50 \mu l$ icteric serum. For further details see text.

The decrease observed at $405 \mathrm{~nm}$ is accompanied by an increase at $546 \mathrm{~nm}$ (fig. 2) suggesting the formation of a red compound from yellow bilirubin in the presence of diazonium salt Fast Red TR. This is further established by the absorption spectra of an ic-

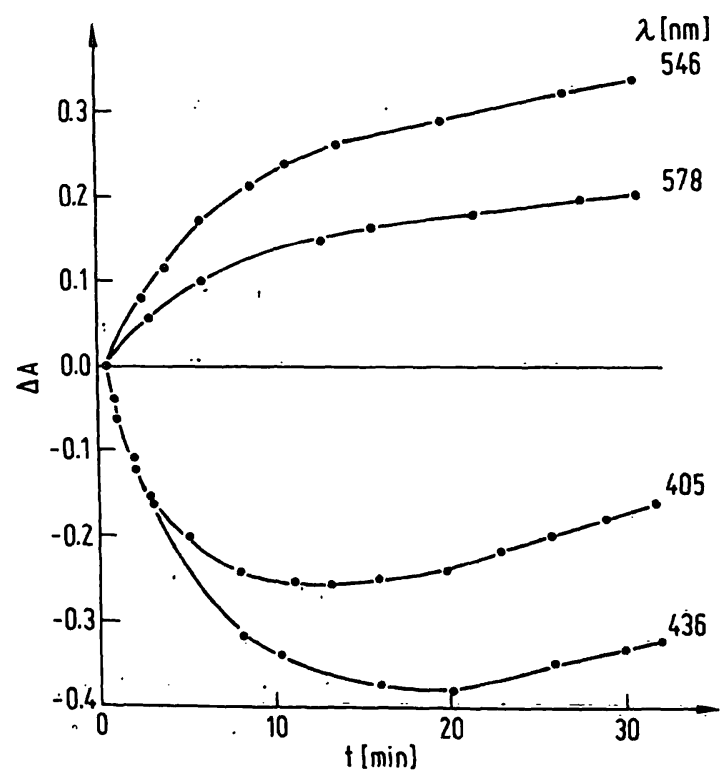

Fig. 2. Acid phosphatase assay, using an icteric serum (bilirubin $259 \mu \mathrm{mol} / \mathrm{l}$, direct bilirubin $176 \mu \mathrm{mol} / \mathrm{l})$. Measurements are performed at $405,436,546$, and $578 \mathrm{~nm}$ at $37^{\circ} \mathrm{C}$. For furthèr details see text. teric serum before and after incubation with Fast Red TR $(0.6 \mathrm{mg} / \mathrm{ml}$ in $0: 2 \mathrm{~mol} / \mathrm{l}$ citrate buffer, $\mathrm{pH}$ 5.2) in the absence of the phosphatase substrate $\alpha$-naphthylphosphate. The absorption decreases between 380 and $479 \mathrm{~nm}$ and increases beyond these isosbestic points (fig. 3 ).

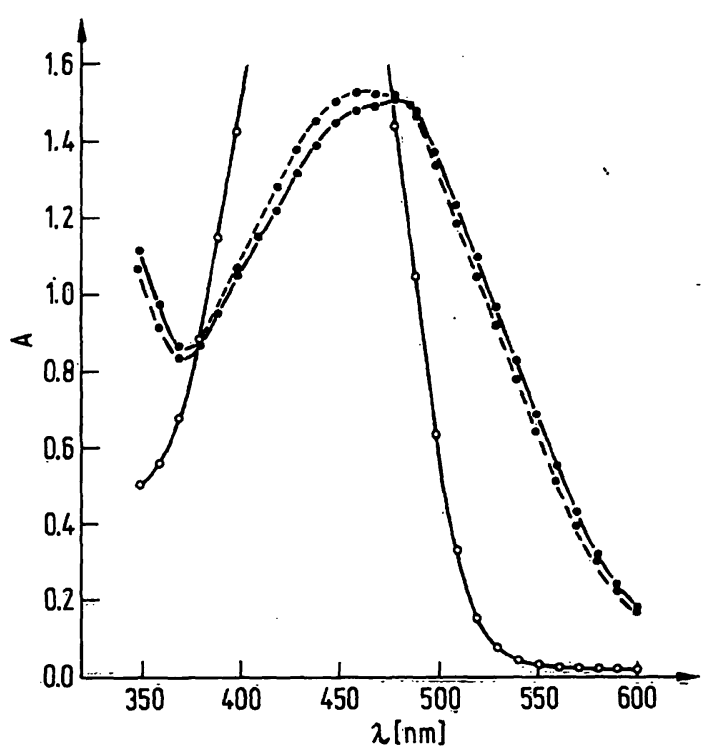

Fig. 3. Absorption spectra of an icteric serum diluted 21 -fold in $0.2 \mathrm{~mol} / \mathrm{l}$ citrate buffer, $\mathrm{pH} 5.2$ before and after incubation with Fast Red TR (final concentration $0.6 \mathrm{~g} / \mathrm{l}$ ). Open circles: before incubation

Filled circles: after incubation for $30 \mathrm{~min}$ (dotted line) and $60 \mathrm{~min}$ (solid line).

The interfering decrease of abssorption is only observed with markedly icteric sera containing direct bilirubin (tab. 1). In contrást, normal and slightly icteric sera (direct bilirubin less than $50 \mu \mathrm{mol} / \mathrm{l}$ ) produce a small increase of absorption at $405 \mathrm{~nm}$ during

Tab. 1. Reaction between direct bilirubin and Fast Red TR in the absence of $\alpha$-naphthylphosphate. Each assay contained $0.5 \mathrm{ml}$ citrate buffer (0.2 mol/1, pH 5.2), $0.3 \mathrm{mg}$ Fast Red $\mathrm{TR}$ and $0.05 \mathrm{ml}$ serum. Absorbances were read at $405 \mathrm{~nm}$ and "pseudoactivities" were calculated from the 5-minvalue using a molär absorption coefficient of $14.1 \times$ $10^{3} \mathrm{l} / \mathrm{mol} \times \mathrm{cm} \mathrm{(4).}$

\begin{tabular}{|c|c|c|c|c|c|}
\hline $\begin{array}{l}\text { Total } \\
\text { bilirubin } \\
\text { ( } \mu \mathrm{mol} / \mathrm{l})\end{array}$ & $\begin{array}{l}\text { Direct } \\
\text { bilirubin } \\
(\mu \mathrm{mol} / \mathrm{l})\end{array}$ & $\begin{array}{l}\Delta_{\mathbf{A}_{405} / \mathrm{min}} \\
\mathbf{1}^{\mathrm{st}} \min \end{array}$ & $\begin{array}{l}\text { recorded } \\
5^{\text {th }} \mathrm{min}\end{array}$ & $\begin{array}{l}\text { within the } \\
10^{\text {th }} \mathrm{min}\end{array}$ & $\begin{array}{l}\text { Pseụdo- } \\
\text { activity } \\
\text { (U/A) }\end{array}$ \\
\hline 27 & 9 & 0.008 & 0.002 & 0.000 & 6.2 \\
\hline 31 & 14 & 0.006 & 0.003 & 0.000 & 2.3 \\
\hline 39 & 17 & 0.007 & 0.002 & 0.000 & 1.6 \\
\hline 58 & 36 & 0.008 & 0.005 & 0.000 & 3.9 \\
\hline 91 & 50 & 0.002 & 0.000 & 0.000 & 0.0 \\
\hline 139 & 84 & -0.028 & -0.008 & 0.000 & -6.2 \\
\hline 142 . & 89 & -0.050 & -0.010 & -0.002 & $-7,8$. \\
\hline 17.3 & 103 & -0.045 & -0.014 & $=0.005$ & -10.9 \\
\hline
\end{tabular}


the first 3 to 5 minutes, even in the absence of a $\alpha$ naphthylphosphate (tab. 1). This transitory "pseudoactivity" may be caused by an azo-coupling reaction between Fast Red TR and some serum components (4). At concentrations of direct bilirubin above $50 \mu \mathrm{mol} / \mathrm{l}$ the typical decrease of absorption is observed at $405 \mathrm{~nm}$ (tab. 1).

In contrast to water-soluble direct bilirubin no interfering reaction is observed with insoluble ("indirect") bilirubin, for example with a commercial bilirubin standard solution or with an icteric neonatal serum (fig. 4). The interfering reaction can, however, be started by addition of an organic solvent such as dimethylformamide (fig. 4).

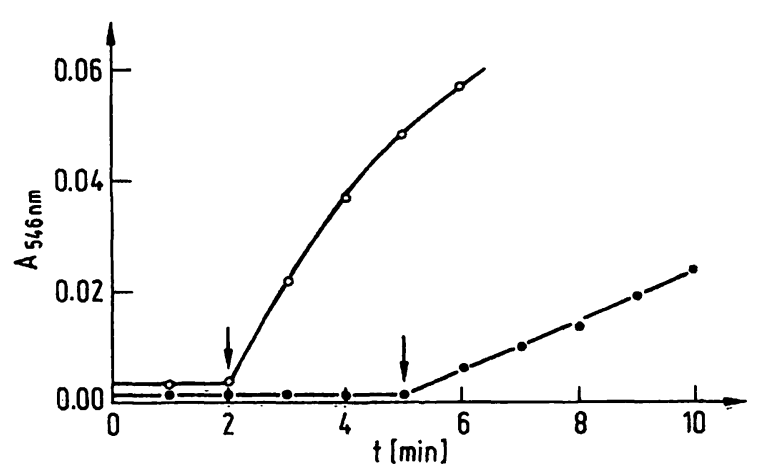

Fig. 4. Influence of dimethylformamide (final concentration 160 $\mathrm{ml} / \mathrm{l}$ ) on the reaction of "indirect" bilirubin with Fast Red TR.

Open circles: bilirubin standard solution $(325 \mu \mathrm{mol} / \mathrm{l})$ Filled circles: neonatal serum (bilirubin $171 \mu \mathrm{mol} / \mathrm{l}$, direct bilirubin $5 \mu \mathrm{mol} / \mathrm{l}$ ).

The arrows indicate the addition of dimethylformamide to a mixture of $1 \mathrm{ml}$ phosphatase reagent (without $\alpha$-naphthylphosphate) and $0.1 \mathrm{ml}$ sample.

\section{Discussion}

In 1977, Shaw et al. (2) reported an inhibiting effect of icteric sera on the acid phosphatase assay of Hillmann (1). The authors were, however, unable to de- monstrate an influence of purified bilirubin, so that the "inhibiting" effect of icteric sera remained doubtful.

In this article, we show that bilirubin does not inhibit acid phosphatase but interferes with the indicator reactions by forming a coloured azo-compound. We have observed that this reaction is greatly dependent on assay conditions such as $\mathrm{pH}$ and presence of albumin or organic solvents (fig. 4). Under the conditions of the Hillmann assay only water-soluble bilirubin derivatives interfere with the phosphatase assay while insoluble bilirubin reacts only in the presence of organic solvents (fig. 4) or at $\mathrm{pH}$-values around 7 (not shown).

At concentrations of direct bilirubin below $50 \mu \mathrm{mol} / \mathrm{l}$ this interference may be partly compensated by a "pseudoactivity" observed in non-icteric sera (4) while at higher concentrations direct bilirubin reduces the measurable phosphatase activity appreciably.

We have observed that the interfering effects of bilirubin are comparable in the presence and absence of tartrate which is added to the assay as an inhibitor of prostatic acid phosphatase (1). Therefore, by expressing prostatic phosphatase activity as the difference between values obtained with and without tartrate, the interference should, theoretically; be eliminated.

The following objections must, however, be considered:

1. Absorbance curves are non-linear in the presence of bilirubin (fig. 1) so that activity measurements become less precise.

2. Absorbance changes caused by bilirubin are usually higher than those induced by acid phosphatase. This enlarges the analytical error.

For these reasons we cannot recommend this kinetic method for the measurement of prostatic acid phosphatase in sera with direct bilirubin above $50 \mu \mathrm{mol} / \mathrm{l}$.

\section{References}

1. Hillmann, G. (1971) J. Clin. Chem. Clin. Biochem. 9, $273-274$

2. Shaw, L. M., Brummond; W. \& Dorio, R. J. (1977). Am. J. Clin. Pathol. 66, 57-62.

3. Warren, R. J. \& Moss, D. W. (1977) Clin. Chim. Acta 77, 179-188.

4. Gundlach, G. \& Mühlhausen, B. (1980) J. Clin. Chem. Clin. Biochem. 18, 603-610.

5. Wahlefeld, A. W., Herz, G. \& Bernt, E. (1972) Scand. J. Clin. Lab. Invest. 29, Suppl. 126, Abstr. 11. 12.

6. Jendrassik, L. \& Grof, P. (1938) Biochem. Z. 297, 81.

Priv. Doz. Dr. med. L. Weiss

Chefarzt des Klin.-Chem. Inst.

Städt. Krankenhaus München-Harlaching

Sanatoriumsplatz 2

D-8000 München 90 
